\title{
Comparing Knowledge of Corneal and Organ Transplantation and Attitudes towards Corneal and Organ Donation among University Health Students in Kumasi - Ghana
}

\author{
Seth Lartey ${ }^{1}$, Ellen K Antwi Adjei ${ }^{2 *}$, Abdul Kabir Mohammed ${ }^{2}$, Derrick N 0 Mensah² and Solomon Agyapong ${ }^{2}$ \\ ${ }^{1}$ Department Eye Ear Nose and Throat, College of Health Sciences, Ghana
}

${ }^{2}$ Department of Optometry and Visual Sciences, Kwame Nkrumah University of Science and Technology, Ghana

Submission: March 28, 2019; Published: June 25, 2019

*Corresponding author: Ellen K Antwi Adjei, College of Science, Faculty of Biosciences, Department of Optometry and Visual Sciences, Kwame Nkrumah University of Science and Technology, Ghana

\begin{abstract}
Background: To determine and compare the level of knowledge of corneal and organ transplant and attitudes towards organ donation among health students at the university level, Kumasi-Ghana.

Methods: A cross sectional descriptive study was conducted on 300 health students at the Kwame Nkrumah University of Science and Technology (KNUST). The data was collected using self-administered questionnaire.

Results: The mean age of the participants was $21.4 \pm 2.9$. The level of awareness of organ transplant was high (95.0\%). There was a statistically significant association between age and awareness of organ transplant $(\chi 2=26.029, p<0.05)$. The level of awareness of corneal transplant was low (45.3\%) as compared to that of organ transplant. Among those aware of organ transplant only $47.7 \%$ were aware of corneal transplant while cornea is the tissue respondents were least willing to donate (4\%). There was a statistically significant association between age $\left(\chi^{2}=17.705, P<0.05\right)$, departments $\left(\chi^{2}=14.822, p<0.05\right)$, academic level $\left(\chi^{2}=11.655, p<0.05\right)$ and awareness of corneal transplant. The main source of information for the current knowledge about transplants for all students was through the digital media (89.5\%) and lectures (55.4\%) Most of the participants knew about kidney (97.5\%) as the most transplanted organ. Most of the participants were willing to donate an organ (57.6\%). The major reasons behind willingness to donate were the love for humanity (61.6\%) and giving others the chance for quality life (58.7\%). Fears of complication after donation (91.4\%) and lack of enough information concerning organ donation (54.4\%) were the main reasons behind unwillingness to donate.
\end{abstract}

Conclusion: There is a low level of awareness of corneal transplant (45.3\%). compared to organ transplants (95.0\%), there is the need to increase the level of knowledge of corneal transplant among the health students through digital media and student curriculum during their ophthalmic rotations.

Keywords: Knowledge; Attitudes; Willingness; Unwillingness; Cornea transplant; Health students

\section{Introduction}

An organ transplant is a surgical procedure where a diseased or damaged organ is replaced with a healthy one. A corneal transplant is where a diseased cornea is replaced with a donor cornea [1,2]. Corneal blindness is an important cause of blindness in Africa and there is an urgent need for corneal banking in the region. Corneal and Organ transplant service is limited or non- existent in large parts of Africa with Nigeria being the only country in West Africa where routine organ transplant takes place [3]. The main critical issue identified in developing countries (e.g. Ghana) or countries that are starting organ transplantation is the lack of a legal and ethical framework governing human organ donation and transplant. Physicians are unable to request for organs of deceased or dying relatives [4]. The major reason associated with these legal limitations is due to the lack of public awareness. Health-care professional have an important role in raising the level of awareness among the public [5]. They play a very important role in the education of the public with the relevant information and correct their misconception regarding corneal and organ transplantation. If they do this adequately, it is likely to increase the number of people willing to donate [6]. Studies have shown that poor knowledge and attitude of the public towards organ donation could be blamed on poor education from the health systems and educational providers [4]. 
There is a need to create awareness in the public to help in the provision of ethical, legal and professional governance framework to this sector which will increase organ donation and transplants. The creating of awareness on organ transplantation and donation may be difficult if the knowledge of health workers and students in this country are inadequate or inaccurate. Therefore, this study seeks to determine and compare the level of knowledge of corneal and organ transplant and attitudes towards organ donation among health students at the university level.

\section{Materials and Methods}

A cross-sectional study was conducted on health students at the Kwame Nkrumah University of Science and Technology (KNUST) Kumasi Ghana. Trainees were from the Optometry and Visual Science Department, School of Medical Sciences, Department of Pharmacy and Pharmaceutical Sciences, KNUST Dental School and Department of Nursing. A multistage sampling was employed to select 300 participants.

A self-administered questionnaire was distributed to participants who met the inclusion criterion. Information gathered from the questionnaire included the demographic of the participant, their awareness and knowledge of organ in general and corneal transplant and their attitudes towards donations. Statistical Package for Social Sciences Software (SPSS) version 23 was used to analyse the data. Chi-square was used to compare the data obtained.

\section{Results}

\section{Socio-demographics of KNUST health student}

Table 1: Socio-demographic characteristics of KNUST health students.

\begin{tabular}{|c|c|c|}
\hline Characteristics & Frequency $(n=300)$ & Percent (\%) \\
\hline \multicolumn{3}{|l|}{ Age } \\
\hline$\leq 17$ & 8 & 2.7 \\
\hline $18-20$ & 78 & 26.0 \\
\hline $21-22$ & 115 & 38.3 \\
\hline $23-25$ & 47 & 15.7 \\
\hline$\geq 26$ & 52 & 17.3 \\
\hline \multicolumn{3}{|l|}{ Gender } \\
\hline Male & 162 & 54.0 \\
\hline Females & 138 & 46.0 \\
\hline \multicolumn{3}{|l|}{ Department } \\
\hline Optometry \& Visual Science & 60 & 20.0 \\
\hline Medicine & 60 & 20.0 \\
\hline Dentistry & 60 & 20.0 \\
\hline Pharmacy & 60 & 20.0 \\
\hline Nursing & 60 & 20.0 \\
\hline \multicolumn{3}{|l|}{ Academic Level } \\
\hline Lower class (1-3/1-2) & 150 & 50 \\
\hline Upper class (3-6/3-4) & 150 & 50 \\
\hline
\end{tabular}

\begin{tabular}{|c|c|c|}
\hline Religion & & \\
\hline Christians & 251 & 83.7 \\
\hline Muslims & 49 & 16.3 \\
\hline Traditionalist & 0 & 0 \\
\hline
\end{tabular}

Lower Class: This include health students from $1^{\text {st }}$ year to $3^{\text {rd }}$ year students from the departments of Optometry, Medicine, Pharmacy and Dentistry as well as $1^{\text {st }}$ and $2^{\text {nd }}$ years from the nursing department.

Upper Class: This include health students from $4^{\text {th }}$ year to $6^{\text {th }}$ year students from the departments of Optometry, Medicine, Pharmacy and Dentistry as well as $3^{\text {rd }}$ and $4^{\text {th }}$ years from the nursing department.

A total of 300 participants from the Optometry and Visual Science Department, School of Medical Sciences, Department of Pharmacy and Pharmaceutical Sciences, Dental School and Department of Nursing. This study had $100 \%$ response rate. The age range of the participants was from 17 to 27 years with a mean age of $21.43 \pm 2.563$. Among the respondents, 162 were males $(54.0 \%)$ and 138 were females $(46.0 \%)$ with majority of them being Christians (83.7\%) (Table 1). The academic level was divided into upper and lower classes with 150 students from each side (Table 1).

\section{Awareness and knowledge of organ transplant among health students}

Table 2: Awareness of Organ Transplant among KNUST Health Student.

\begin{tabular}{|c|c|c|c|}
\hline Characteristics & Aware n (\%) & Not Aware n (\%) & p-value \\
\hline \multicolumn{4}{|l|}{ Age } \\
\hline$\leq 17$ & $3(37.5)$ & $5(62.5 \%)$ & $0.000^{*}$ \\
\hline $18-20$ & 77 (98.7) & $1(1.3)$ & \\
\hline $21-22$ & 109 (94.8) & $6(5.2)$ & \\
\hline $23-25$ & $44(93.6)$ & $3(6.4)$ & \\
\hline$\geq 26$ & $52(100.0)$ & $0(0.0)$ & \\
\hline \multicolumn{4}{|l|}{ Gender } \\
\hline Male & $158(97.5)$ & $4(2.5)$ & 0.290 \\
\hline Females & $127(84.8)$ & $11(15.2)$ & \\
\hline \multicolumn{4}{|l|}{ Department } \\
\hline $\begin{array}{l}\text { Optometry \&Visual } \\
\text { Science }\end{array}$ & $59(98.3)$ & $1(1.7)$ & 0.477 \\
\hline Medicine & $57(95.0)$ & $3(5.0)$ & \\
\hline Dentistry & 55 (91.7) & $5(8.3)$ & \\
\hline Pharmacy & $56(93.3)$ & $4(6.7)$ & \\
\hline Nursing & $58(96.7)$ & $2(3.3)$ & \\
\hline \multicolumn{4}{|l|}{ Academic Level } \\
\hline Lower class $(1-3 / 1-2)$ & $153(94.4)$ & $12(5.6)$ & 0.027 \\
\hline Upper class $(3-6 / 3-4)$ & $132(97.8)$ & $3(2.2)$ & \\
\hline \multicolumn{4}{|l|}{ Religion } \\
\hline Christians & $240(95.6)$ & $11(4.4)$ & 0.267 \\
\hline Muslims & 45 (91.8) & $4(8.2)$ & \\
\hline Traditionalist & 0 & 0 & \\
\hline
\end{tabular}

$\mathrm{n}(\%)$ represents the frequencies and percentages of characteristics of respondents.

${ }^{*} \mathrm{P}<0.05$ is statistically significant. 
Table 2 summarizes the awareness of organ transplant among KNUST health students. The awareness of organ transplant was high with 285 (95\%) of the participants aware of organ transplant with similar response rate among the departments. This study employs the grading system of awareness of organ transplant by Alex et al. [7] where high is above 75\%, average is from $50 \%-75 \%$ and poor if below $50 \%$. The awareness level of the male students $(97.5 \%)$ was greater than that of the female student (84.8\%). There was a significant association between age and the awareness of organ transplant $(\chi 2=26.029, \mathrm{p}<0.05)$ (Table 2). The major source of information was the digital media accounting for $89.5 \%$ followed by the Lectures (55.4\%). (Table 3). Kidney (97.5\%) transplant had the highest response in terms of their knowledge on the organs that can be transplanted whiles others (Hairs and Lungs) recording the least with 2.8\% (Table 3). Majority (74.7\%) of the participants knew that organs can be donated both while living and after death (Table 3).

Table 3: Knowledge of Organ Transplants among KNUST Health Student.

\begin{tabular}{|c|c|c|}
\hline Knowledge of Organ Transplant & Frequency (n) & Percent (\%) \\
\hline \multicolumn{3}{|l|}{ Source of Information* } \\
\hline Digital media & 255 & 89.5 \\
\hline Newspapers & 106 & 37.2 \\
\hline Lecturers & 158 & 55.4 \\
\hline Health care providers & 149 & 52.3 \\
\hline Family & 56 & 19.6 \\
\hline Friends & 100 & 35.1 \\
\hline Others & 3 & 1.1 \\
\hline \multicolumn{3}{|l|}{$\begin{array}{l}\text { Which organs or tissues do you } \\
\text { know can be transplanted? }\end{array}$} \\
\hline Liver & 197 & 69.1 \\
\hline Heart & 253 & 88.8 \\
\hline Kidney & 278 & 97.5 \\
\hline Cornea & 149 & 52.3 \\
\hline Bone & 104 & 36.5 \\
\hline Skin & 127 & 44.6 \\
\hline Others (Hair \& Lungs) & 8 & 2.8 \\
\hline \multicolumn{3}{|l|}{$\begin{array}{l}\text { When can body organs be donated? } \\
\qquad(\mathrm{n}=285)\end{array}$} \\
\hline After death & 15 & 5.3 \\
\hline Whilst Living & 57 & 20 \\
\hline
\end{tabular}

${ }^{*}$ multiple responses allowed.

\section{Awareness and knowledge of corneal transplant among KNUST health student}

Table 4: Awareness of Corneal Transplant among KNUST Health Students aware of organ transplant, $\mathrm{n}=285$.

\begin{tabular}{|c|c|c|c|}
\hline Characteristics & Aware n (\%) & Not Aware n (\%) & p-value \\
\hline Age & & & \\
\hline$\leq 17$ & $1(33.3)$ & $2(66.7)$ & $0.000^{*}$ \\
\hline $18-20$ & $21(27.3)$ & $56(72.7)$ & \\
\hline $21-22$ & $55(50.5)$ & $54(49.5)$ & \\
\hline
\end{tabular}

\begin{tabular}{|c|c|c|c|}
\hline $23-25$ & $31(70.5)$ & $13(29.5)$ & \\
\hline$\geq 26$ & $28(53.8)$ & $24(46.2)$ & \\
\hline \multicolumn{4}{|l|}{ Gender } \\
\hline Male & $86(54.4)$ & $72(45.6)$ & $0.007^{*}$ \\
\hline Females & $50(39.4)$ & $77(60.6)$ & \\
\hline \multicolumn{4}{|l|}{ Department } \\
\hline $\begin{array}{l}\text { Optometry \&Visual } \\
\text { Science }\end{array}$ & $52(88.1)$ & 7 (11.9) & $0.000^{*}$ \\
\hline Medicine & $20(35.7)$ & $36(64.3)$ & \\
\hline Dentistry & $24(44.4)$ & $30(55.6)$ & \\
\hline Pharmacy & $19(32.2)$ & $40(67.8)$ & \\
\hline Nursing & $21(36.8)$ & $36(63.2)$ & \\
\hline \multicolumn{4}{|l|}{ Academic Level } \\
\hline Lower class $(1-3 / 1-2)$ & $57(37.3)$ & $96(62.7)$ & $0.000^{*}$ \\
\hline Upper class $(3-6 / 3-4)$ & $79(59.8)$ & $53(40.2)$ & \\
\hline \multicolumn{4}{|l|}{ Religion } \\
\hline Christians & $123(51.3)$ & 117 (48.7) & $0.010^{*}$ \\
\hline Muslims & $13(28.9)$ & $32(71.9)$ & \\
\hline Traditionalist/others & 0 & 0 & \\
\hline
\end{tabular}
$\mathrm{n}=285$.

$n(\%)$ represents the frequencies and percentages of characteristics of respondents.

${ }^{*} \mathrm{P}<0.05$ is statistically significant.

Table 5: Knowledge of Corneal Transplants among KNUST health students aware of corneal transplant, $\mathrm{n}=136$.

\begin{tabular}{|c|c|c|}
\hline Knowledge of Corneal Transplant & Frequency (n) & Percent (\%) \\
\hline $\begin{array}{c}\text { Which of the following do } \\
\text { you believe is true of corneal } \\
\text { transplant? }\end{array}$ & 57 & 41.9 \\
\hline $\begin{array}{c}\text { It is done to replace the whole eye } \\
\text { It is done to replace part of a } \\
\text { diseased eye }\end{array}$ & 79 & 58.1 \\
\hline $\begin{array}{c}\text { When can body organs be } \\
\text { donated? }\end{array}$ & & \\
\hline After death & 62 & 45.6 \\
\hline Whilst Living & 27 & 19.9 \\
\hline Both & 45 & 33 \\
\hline Non-response & 2 & 1.5 \\
\hline
\end{tabular}

The level of awareness of corneal transplant was low (45.3\%) compared to awareness of organ transplant (95.0\%) among the entire respondents $(n=300)$. Among those who were aware of organ transplant, $47.7 \%$ were aware of corneal transplant (Table 4). 54.4\% of the male participants among those who were aware of organ transplant were also aware of corneal transplant with lower findings in females (39.4\%) (Table 4). Optometry department had the highest level of cornea awareness compared to the other departments among the respondents who were aware of organ transplant. In this study, upper class participants showed a higher level (59.8\%) of awareness compared to the lower classes (37.3\%). Christians (51.3\%) were more aware of corneal transplant than Muslims (28.9\%) for the awareness of 
corneal transplant among the health student (Table 4). There was a significant association between age, gender, departments and academic level and awareness of corneal transplant (Table 4). Among the participants who were aware of corneal transplant, $58.1 \%$ believed that corneal transplant is done to replace part of a diseased eye and corneas can be donated after death (45.6\%) (Table 5).

\section{Attitudes towards organ or tissue donation}

Table 6: Reason for willingness to donate.

\begin{tabular}{|c|c|c|}
\hline Reasons* & Frequency (n) & Percent (\%) \\
\hline Love for humanity & 106 & 61.6 \\
\hline A noble gesture & 74 & 43 \\
\hline My religious obligation & 7 & 4 \\
\hline Kindness & 26 & 15.1 \\
\hline $\begin{array}{c}\text { Give others a chance for a better } \\
\text { quality of life }\end{array}$ & 101 & 58.7 \\
\hline Others (Financial) & 6 & 3.5 \\
\hline
\end{tabular}

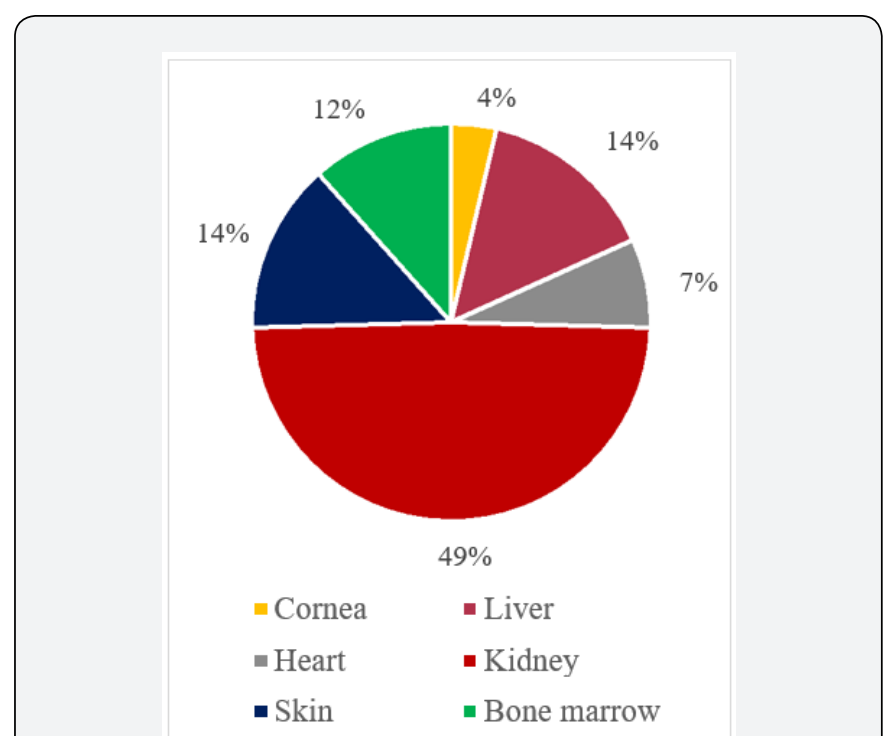

Figure 1: Organs and tissues participants are willing to donate.

Out of the 300 respondents, 172 (57.3\%) students were willing to donate an organ or tissue and out of which 109 (63.4\%) were willing to donate after death and 63(36.6\%) whilst living. For those who were willing to donate an organ, the major reason behind their decisions was the love for humanity (33.1\%) among the multiple responses (Table 6) and the kidney (Figure 1) was the organ most of them were willing to donate. Out of 128 students who were unwilling to donate, their main reason among the multiple responses was the fears of complications after donation (91.4\%). None of the respondents cited religious believes or cultural taboo as a reason for their unwillingness to donate.

\section{Discussion}

\section{Awareness and knowledge on organ transplant}

The level of awareness of organ transplant was 95\%, like findings by Sobnach et al. [8] in a study conducted in South
Africa among medical students showing 96\% level of awareness. Similar findings were reported by Mane et al. [9] with $100 \%$ level of awareness and $97 \%$ by Bapat et al. [10] on post graduate medical students. The higher level of awareness may be due to the publicity given to organ transplant by the media. A study conducted on nursing students by Sukhpal kaur \& Sandhya Ghai [11] indicated that the major source of information concerning organ transplant was from television which is similar to this study where $89.55 \%$ of the respondents indicated that, the major source of information is from the digital media (television, radios and social media) $[11,12]$.

However, a study by Figueroa et al. [13] \& Chen et al. [14] showed different results from this present study with the print media accounting for their major source of information. The growth of social media over the years might contribute to the reason why it is the major source of information in this study. This study revealed that $97.5 \%$ of the participants had knowledge about kidney transplant. According to Alex et al. [7], kidney transplant had the highest response $(94 \%)$ in a study conducted on medical students from South India with similar response (88\%) among medical students in South Africa [8]. The higher response on kidney transplant might be attributed to the fact that the kidney is the most transplanted organ globally.

\section{Awareness and knowledge on corneal transplant}

Corneal diseases are the one of leading causes of blindness and visual impairment globally with majority of them in developing countries [15]. The level of awareness among current and future health care workers will influence the attention that is drawn to cornea transplant. The level of awareness on corneal transplant in this study is low (45.3\%) compared to Ahirwar et al. [15] with $81 \%$, Sanjeev et al. [16] with $98 \%$ and a Nigerian study [17] indicating that $75.9 \%$ of medical doctors are aware of corneal transplant. Corneal transplant is in its formative stage in Ghana resulting in the lower level of awareness compared to other countries.

According to Singh et al. [18], majority of the medical students (99.4\%) knew that cornea was donated after death but $45.6 \%$ knew that the cornea was donated after death in this study whiles Gupta et al. [19] had a lower finding of $32.8 \%$. The poor knowledge of when the cornea is donated can be attributed to low awareness of cornea transplant among the participants in this study. Moreover, Optometry students had the highest level of knowledge about corneal transplants, these are students specialising in the study of eyes.

\section{Attitudes towards organ or tissue donation}

In this study, despite the high level of awareness of organ transplant, the attitude towards organ donation was low. 57.3\% were willing to donate an organ or tissue in this study compared to medical student in India (68.82\%) [7]. Among the participants, $63.4 \%$ were willing to donate after death and $36.6 \%$ whilst living. A study conducted in Netherlands [20] revealed that most of the 
respondent were willing to donate after death, like this study. Most of the participant in the study indicated that, they were open for their body organs to be used to save lives after death because of their love for humanity.

This study showed that $78.5 \%$ preferred donating their kidneys which is higher than the findings from Patel et al. [21] (40\%). $4.0 \%$ were willing to donate their corneas compared to a study done by Abadom et al. [17] in Nigeria which $33.3 \%$ of medical doctors were willing to donate their corneas and $46.75 \%$ by Sanjeev et al. [16]. The high knowledge of the participants in kidney transplant could be a factor for the higher willingness to donate. Also, another factor may be that since most individuals can live with one of their kidneys, donating one of their paired kidneys would help improve the life's of others.

$42.7 \%$ were unwilling to donate any organ or tissue. The fear of complication after donation (91.4\%) was the major reason accounting for the unwillingness to donate. Other factors including the lack of information concerning donation (54.4\%) and the lack of trust in the health system $(51.1 \%)$ influenced their choice. A study conducted by Keçecioğlu et al. [22] confirmed that the main reason for the lack of organ donation among the public was insufficient knowledge which is similar to a study conducted in Abadom et al. [17] and Hamed and Elhosseny Awad [5]. The main reason for the refusal of donation among UK nurses is disfigurement post-mortem which is not the same in this study. This study was conducted on one university, therefore limiting the ability to generalize results.

\section{Conclusion}

This study showed that there was a very high level (95\%) of awareness of organ transplant as compared to a low level (45.3\%) of awareness of corneal transplant in university health students. Among those aware of organ transplant only $47.7 \%$ were aware of corneal transplant while cornea is the tissue respondents were least willing to donate (4\%). The main source of information for the current knowledge about transplants for all students was through the digital media (89.5\%) and lectures (55.4\%). The main reasons for unwillingness to donate organs and tissues were fear of complication (91.4\%) and inadequate information (54.4\%). There is a need to create awareness through the digital media and by curriculum review of health student ophthalmic rotation to include detailed education on corneal transplantations.

\section{Declarations}

\section{Ethics approval and consent to participate}

Ethical approval was obtained from the Committee on Human Research, Publication \& Ethics (CHRPE) of the Kwame Nkrumah University of Science and Technology. Informed consent was obtained from all the participants.

\section{Availability of Data and Material}

The datasets generated and/or analysed during the current study are available in the HARVARD Dataverse repository, https:// doi.org/10.7910/DVN/8WWMYX

\section{Authors' Contributions}

SL conceived the researchideas. SL, EKAA and AKM contributed to the conception, topic and the research designs. SA and NODM participated in the writing, workflow and data collection. SL, EKAA, AKM, NODM and SA participated in the interpretation of data and analysis while NODM wrote the first draft. SL and EKAA reviewed the first draft and offered substantial revisions which was incorporated into the subsequent and final drafts. All authors read and approved the final manuscript as submitted and take full responsibility for the manuscript.

\section{Acknowledgements}

All the departmental heads of the selected departments.

\section{References}

1. Saleem T, Ishaque S, Habib N, Hussain SS, Jawed A, et al. (2009) Knowledge, attitudes and practices survey on organ donation among a selected adult population of Pakistan. BMC Medical Ethics 10: 5.

2. Bowling B (2016) Kanski: Oftalmología Clínica, Clinical Ophthalmology. A systematic approach.

3. Persy VP (2010) Prevention and transplantation in chronic kidney disease: what is achievable in emerging countries? Nephron. Clinical practice 115(2): 122-132.

4. El Shoubaki H, Bener A (2005) Public Knowledge and Attitudes toward organ donation and transplantation: a cross-cultural study. Transplant Proc 37(5): 1993-1997.

5. Hamed H, Awad ME, Youssef KN, Fouda BE, El Nakeeb A, et al. (2015) Knowledge and Attitudes about Organ Donation among Medical Students in Egypt: A Questionnaire. Journal of Transplantation Technologies \& Research 8: 48.

6. Alghanim SA (2010) Knowledge and attitudes toward organ donation: a community-based study comparing rural and urban populations. Saudi J Kidney Dis Transpl 21(1): 23-30.

7. Alex P, Kiran KG, Baisil S, Badiger S (2017) Knowledge and attitude regarding organ donation and transplantation among medical students of a medical college in South India. Int J Community Med Public Health 4(9): 3449-3454.

8. Sobnach S, Borkum M, Hoffman R, Muller E, McCurdie F, et al. (2010) Medical students' knowledge about organ transplantation: A South African perspective. Transplant Proc 42(9): 3368-3371.

9. Mane V, Markam J, William RF, Vidya DC, Naik TB (2016) Organ donation: An assessment of Knowledge, Attitude and Practices among Medical Students. Indian Journal of Forensic and Community Medicine 3(4): 284-287.

10. Bapat U, Kedlaya PG, Gokulnath (2009) Organ donation, awareness, attitudes and beliefs among post graduate medical students. Saudi Kidney Dis Transpl 20(1): 174-180.

11. Sukhpal Kaur, Sandhya Ghai NK (2015) Knowledge, Attitude and Perception Regarding Organ Donation among the Nursing Students. Journal of Postgraduate Medicine, Education and Research 49: 105-110.

12. Iliyasu Z, Abubakar IS, Lawan UM, Abubakar M, Adamu B (2014) Predictors of public attitude toward living organ donation in Kano, northern Nigeria. Saudi Journal of Kidney Diseases and Transplantation 25(1): 196-205. 
13. Figueroa CA, Mesfum ET, Acton NT, Kunst AE (2013) Medical students knowledge and attitudes toward organ donation: Results of a Dutch survey. Transplantation Proceedings 45(6): 2093-2097.

14. Chen MC, Kunselman AR, Stetter CM, Hannush SB, Roberts BW (2017) Corneal transplantation at Tenwek Hospital, Kenya, East Africa: Analysis of outcomes and associated patient socioeconomic characteristics. PLoS ONE 12(10).

15. Ahirwar RK, Shidhaye PR, Ekka IJ, Saxena DM (2016) Study of knowledge and willingness regarding eye donation among medical students of a tertiary care teaching hospital of central India 3(9): 2363-2368.

16. Sanjeev K, Shukla US, Prakash A (2012) Awareness and knowledge on eye donation among students at Bhopal. National Journal of Community Medicine 3(4): 685-689.

17. Abadom EG, Otene CI, Enivwenae AO (2014) Knowledge and willingness to donate eye among medical doctors in delta state. Journal of Dental and Medical Sciences 13(6): 57-63.
18. Singh MM, Rahi M, Pagare Dand, Ingle GK (2007) Medical students' perception on eye donation in Delhi. Indian journal of ophthalmology 55(1): 49-53.

19. Gupta A, Jain S, Jain T, Gupta K (2009) Awareness and perception regarding eye donation in students of a nursing college in Bangalore. Indian Journal of Community Medicine 34(2): 122-125.

20. Bolt S, Eisinga R, Venbrux E, Kuks JB, Gerrits PO (2011) Personality and motivation for body donation. Annals of Anatomy 193(2): 112-117.

21. Patel A, Sanghavi S, Diwan J (2015) Study of Level of Awareness and Knowledge About the Organ Donation In Undergraduate Medical Students. National Journal of Integrated Research in Medicine 6(4): 78-81.

22. Keçecioğlu N, Tuncer M, Yücetin L, Akaydin M, Yakupoğlu G (2000) Attitudes of religious people in Turkey regarding organ donation and transplantation. Transplantation Proceedings 32(3): 629-630.

\section{Your next submission with Juniper Publishers will reach you the below assets}

- Quality Editorial service

- Swift Peer Review

- Reprints availability

- E-prints Service

- Manuscript Podcast for convenient understanding

- Global attainment for your research

- Manuscript accessibility in different formats

( Pdf, E-pub, Full Text, Audio)

- Unceasing customer service

Track the below URL for one-step submission

https://juniperpublishers.com/online-submission.php 